\title{
JIMMBA
}

\section{Pengaruh Keterlibatan Kerja dan Kepuasan Kerja Terhadap Kinerja dengan Komitmen Organisasi Sebagai Variabel Intervening}

\author{
Rini Susilowati ${ }^{1}$, Siti Nur Azizah ${ }^{2}$ \\ 1,2 Sekolah Tinggi Ilmu Ekonomi Putra Bangsa \\ Email: rinisusilowati339@gmail.com ${ }^{1}$, sitinuraziz@yahoo.com²
}

\section{ARTICLE INFO}

Article History:

Received: July $8^{\text {th }} 2020$

Accepted: October $16^{\text {st }} 2020$

Published: October 21 2020

Keywords:

Keterlibatan Kerja,

Kepuasan Kerja, Kinerja,

Komitmen Organisasi

\begin{abstract}
Penelitian ini bertujuan untuk menganalisis tingkat Kinerja Pegawai PNS di Dinas Sosial dan Pengendalian Penduduk dan Keluarga Berencana Kabupaten Kebumen. Populasi dalam penelitian ini adalah pegawai PNS di Dinas Sosial dan Pengendalian Penduduk dan Keluarga Berencana Kabupaten Kebumen yang berjumlah 34 responden. Penelitian ini menggunakan metode analisis deskriptif dan statistika dengan metode non probability sampling dan jenis tekniknya yaitu sampel jenuh. Berdasarkan metode statistika dilakukan uji validitas, uji reliabilitas, uji asumsi klasik, uji hipotesis, analisis korelasi, analisis jalur, dan uji sobel. Hasil penelitian ini menunjukkan bahwa berdasarkan uji validitas dan uji reliabilitas semua variabel dinyatakan valid dan reliabel. Hasil penelitian menunjukkan bahwa variabel Keterlibatan Kerja berpengaruh positif dan signifikan terhadap Komitmen Organisasi. Kepuasan Kerja berpengaruh positif dan signifikan terhadap Komitmen Organisasi. Keterlibatan Kerja tidak berpengaruh terhadap Kinerja. Kepuasan Kerja tidak berpengaruh terhadap Kinerja, Komitmen Organisasi berpengaruh positif dan signifikan terhadap Kinerja, serta Komitmen Organisasi dapat memediasi antara Keterlibatan Kerja dan Kepuasan Kerja terhadap Kinerja.
\end{abstract}

\section{Pendahuluan}

Zaman era globalisasi yang saat ini semakin berkembang dan maju, organisasi dituntut untuk menciptakan Sumber Daya Manusia yang berkualitas sehingga mampu mencapai suatu tujuan organisasi dengan baik. Hal tersebut senada dengan yang dikatakan oleh Hasibuan (2002: 10) sumber daya manusia merupakan ilmu dan seni untuk mengatur hubungan dan peranan tenaga kerja agar efektif dan efisien membantu terwujudnya tujuan organisasi, pegawai dan juga masyarakat. Sumber Daya Manusia dalam sebuah organisasi memegang peran yang sangat penting dalam proses jalannya organisasi, karena dengan Sumber Daya Manusia organisasi mampu melaksanakan tujuan dan harapan yang sudah ditetapkan oleh organisasi tersebut. Demikian halnya dengan aparat Pemerintah Kabupaten Kebumen di Dinas Sosial dan Pengendalian Penduduk dan Keluarga Berencana Kabupaten Kebumen 
sebagai pengabdi masyarakat dan pengabdi pemerintah, dituntut untuk dapat memberikan pelayanan yang terbaik kepada masyarakat karena hal tersebut sudah merupakan fungsi dan tanggung jawab yang harus dijalankannya.

Setiap organisasi dalam melaksanakan rencana strategisnya selalu diarahkan untuk mencapai tujuan yang diharapkannya. Selain itu juga dituntut untuk mampu menyesuaikan diri dengan lingkungan dan perkembangan yang terjadi secara terus menerus. Oleh karena itu pasti munculah permasalahan yang terjadi di organisasi berkaitan dengan kinerja yang tinggi untuk meningkatkan organisasi lebih maju. Menurut Mangkunegara (2000: 67) bahwa kinerja karyawan adalah hasil kerja secara kualitas dan kuantitas yang dicapai oleh seseorang karyawan dalam melaksanakan tugasnya sesuai dengan tanggung jawab yang diberikan kepadanya. Hal ini menunjukkan bahwa kinerja di Dinas Sosial dan Pengendalian Penduduk dan Keluarga Berencana Kabupaten Kebumen sudah memiliki kualitas pegawai yang baik, yang sudah memberikan hasil kerja maksimal dan mampu menjalankannya sesuai dengan tujuan organisasi. Seorang pegawai dapat memberikan hasil kerja yang baik, supaya bisa meningkatkan kinerja untuk lebih baik lagi. Hal ini dibuktikan dengan hasil wawancara peneliti mengenai variable kinerja, bahwa kinerja seorang pegawai di organisasi tersebut sudah membuktikan dengan adanya hasil pencapaian yang dilakukan seorang pegawai dalam hasil kerjanya yang sesuai dengan tujuan organisasinya.

Pegawai yang bekerja di suatu organisasi, baik organisasi pemerintah ataupun swasta mengharapkan penghidupan yang layak. Ketika seorang organisasi merasa terpenuhi kebutuhannya maka akan timbul rasa komitmen pegawai terhadap organisasinnya. Komitmen organisasi merupakan tingkatan di mana seseorang pegawai memihak pada suatu organisasi tertentu dan tujuan-tujuannya dan berniat memelihara keanggotaan dalam organisasi itu. Hadirnya komitmen organisasi tentunya mempengaruhi kemauan kerja pegawai terhadap organisasinya untuk meningkatkan kinerja. Pegawai yang menganggap dirinya adalah bagian dari perusahaan tentunya mendorong motivasi untuk bekerja secara aktif dalam pelaksanaan kerjanya. Pegawai dengan tingkat kemauan kerja yang tinggi akan menyumbangkan ide untuk kemajuan pekerjaan, dengan senang hati memenuhi peraturanperaturan perusahaan dan mendukung kebijakan perusahaan. Menurut Hasibuan (2007) loyalitas merupakan kesetiaan yang dicerminkan oleh kesediaan pegawai menjaga dan membela organisasi di dalam maupun di luar pekerjaan dari rong-rongan orang yang tidak bertanggung jawab. Hal ini menunjukkan bahwa ketika seorang pegawai bertanggung jawab atas pekerjaannya dengan mencurahkan waktu, tenaga hingga pikirannya kepada organisasi dan pegawai bekerja keras untuk kelancaran semua tugas yang diberikan oleh organisasi tersebut maka akan membantu organisasi untuk lebih baik.

Selain komitmen organisasi terdapat faktor lain yang berpengaruh terhadap kinerja yaitu keterlibatan kerja yang dilakukan oleh organisasi untuk sering melibatkan pegawainya dalam pekerjaan baik di luar maupun di dalam kantor. Menurut Robbins dan Judge (2010: 142) keterlibatan kerja diartikan sebagai suatu ukuran sampai dimana individu secara psikologis memihak pekerjaan mereka dan menganggap penting tingkat kinerja yang dicapai sebagai penghargaan diri. Keterlibatan kerja mempunyai konsekuensi berupa hasil kerja yang diperoleh pegawai untuk organisasinnya. Oleh karena itu dengan semakin terlibatnya pegawai dalam pekerjaan, maka pegawai diharapkan dapat selalu berpartisipasi dalam pekerjaan apapun yang dilakukan oleh organisasi. Seorang pegawai menunjukkan bahwa pekerjaan sebagai yang utama dalam pekerjaannya, dengan cara pegawai tersebut memprioritaskan pekerjaan tersebut di dalam organisasi. Menurut Rivai dan Mulyadi (2012: 246) menyatakan bahwa keterlibatan kerja adalah derajat sejauhmana seseorang memihak secara psikologis terhadap pekerjaannya dan menganggap tingkat kinerjanya penting untuk 
harga diri. Hal ini dibuktikan bahwa pegawai telah memandang pekerjaannya sebagai sesuatu yang penting bagi harga dirinya, karena dengan mementingkan pekerjaan di dalam organisasi pegawai akan merasakan bahwa dirinya penting dan akan selalu terlibat dalam pekerjaannya.

Faktor yang membentuk komitmen organisasi dalam meningkatkan kinerja juga dipengaruhi oleh kepuasan kerja pegawai, dimana pegawai merasa puas dengan apa yang dikerjakan dan sesuai dengan kemampuan yang dimilikinya. Menurut Luthas (2006) kepuasan kerja merupakan keadaan emosi senang atau emosi positif yang berasal dari penilaian pekerjaan atau pengalaman seseorang. Pegawai yang merasa puas terhadap pekerjaannya akan membuat pegawai mendorong terbentuknya perilaku yang baik dari dalam diri yang lebih besar untuk membantu rekan kerja yang lain dan membuat kinerja pegawai menjadi lebih tinggi. Pekerjaan yang dijalani dengan baik di dalam organisasi ini karena terdapat lingkungan kerja yang baik juga, sehingga pegawai merasa puas dengan pekerjaanya. Selain itu juga terdapat hubungan yang baik terhadap atasan maupun dengan rekan kerja, pegawai tersebut saling membantu untuk pekerjaan apapun kepada rekan kerjanya dan atasan selalu ramah dalam menyikapi setiap pekerjaan yang dilakukan oleh pegawainya. Hal ini sejalan dengan penelitian oleh Handayani dan Hariyanti (2011) dan Soegihartono (2012), mengidentifikasikan bahwa kepuasan kerja yang semakin tinggi dapat meningkatkan komitmen organisasi yang ada di dalam organisasi. Berdasarkan hasil wawancara pada pegawai Dinas Sosial dan Pengendalian Penduduk dan Keluarga Berencana Kabupaten Kebumen tentang kepuasan kerja, bahwa pegawai Dinas Sosial dan Pengendalian Penduduk dan Keluarga Berencana Kabupaten Kebumen merasa puas terhadap gaji yang diterima. Pegawai yang puas terhadap pekerjaanya cenderung berbicara yang positif terhadap organisasinya dan membantu pegawai lain dalam pekerjaan.

\section{Kajian Teori dan Telaah Literatur}

\section{Kinerja}

Menurut Mangkunegara (2000: 67) bahwa kinerja karyawan adalah hasil secara kualitas dan kuantitas yang dicapai oleh seseorang karyawan dalam melaksanakan tugasnya sesuai dengan tanggung jawab yang diberikan kepadanya. Sesuai dengan indikator kinerja menurut Robbins (2006), pada penelitian ini kinerja dibatasi pada: (1) Kualitas Kerja; (2) Kuantitas; (3) Ketepatan Waktu; (4) Efektivitas; (5) Kemandirian.

\section{Komitmen Organisasi}

Menurut Robbins (2006), mengatakan bahwa komitmen organisasonal sebagai sikap dimana karyawan dapat merefleksikan perasaan suka atau duka terhadap organisasi. Sesuai dengan indikator komitmen organisasi menurut Lincoln dan Neale, dkk (1990), pada penelitian ini komitmen organisasi dibatasi pada: (1) Kemauan Karyawan; (2) Kesetiaan Karyawan; Kebangaan Karyawan pada Organisasi.

\section{Keterlibatan Kerja}

Menurut Robbins dan Judge (2010: 142) keterlibatan kerja diartikan sebagai suatu ukuran sampai dimana individu secara psikologis memihak pekerjaan mereka dan menganggap penting tingkat kinerja yang dicapai sebagai penghargaan diri. Sesuai dengan indikator keterlibatan kerja menurut Robbins dan Judge (2008), pada penelitian ini keterlibatan kerja dibatasi pada: (1) Aktif berpartisipasi dalam pekerjaan; (2) Menunjukkan pekerjaan sebagai yang utama; (3) Melihat pekerjaannya sebagai sesuatu yang penting bagi harga dirinya. 


\section{Kepuasan Kerja}

Menurut Robbins (2006) kepuasan kerja adalah sikap umum terhadap pekerjaan seseorang yang menunjukkan perbedaan antara jumlah penghargaan yang diterima dan jumlah yang diyakini seharusnya mereka terima. Sesuai dengan indikator kepuasan kerja menurut Robbins (2013), pada penelitian ini kepuasan kerja dibatasi pada: (1) Pekerjaan itu sendiri (work it self); (2) Gaji/ Upah (Pay); (3) Promosi (Promotion); (4) Pengawasan (Supervision); (5) Rekan Kerja (workers).

\section{Model Empiris}

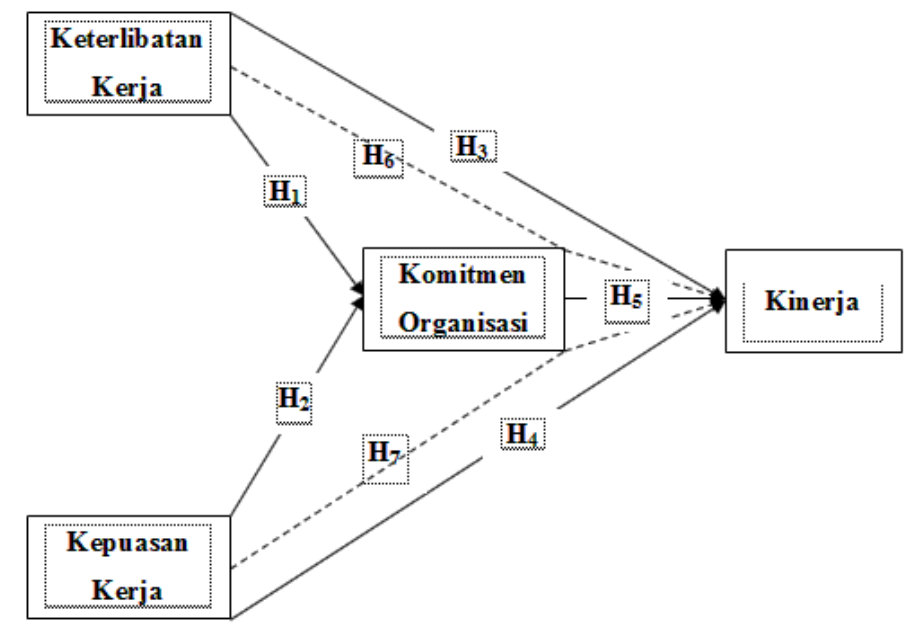

\section{Gambar 1. Model Empiris}

\section{Metode Penelitian}

Rancangan metode penelitian ini menggunakan pengujian hipotesis dan jenis penelitian merupakan penelitian kuantitatif. Populasi pada penelitian ini adalah pegawai PNS di Dinas Sosial dan Pengendalian Penduduk dan Keluarga Berencana Kabupaten Kebumen sejumlah 34 pegawai dan metode pengambilan sampel menggunakan teknik non probability sampling yaitu sampel jenuh.

Teknik pengumpulan data yang dilakukan dengan cara: (1) kuesioner; (2) studi pustaka; (3) wawancara. Alat bantu pengolahan data menggunakan SPSS for windows versi 21.0. Teknik analisis data dilakukkan dengan dua cara yaitu analisis deskriptif dan analisis statistik. Analisis data secara statistik meliputi: (1) Uji Validitas dan Reliabilitas; (2) Uji Asumsi Klasik; (3) Uji Hipotesis; (4) Analisis Korelasi; (5) Analisis Jalur; (6) Uji Sobel.

\section{Hasil dan Pembahasan}

\section{Uji Validitas}

Penelitian ini menggunakan dasar analisi dari Ghozali (2009: 49) dengan menggunakan level of significance $5 \%$, maka: 
a. Jika $\mathrm{r}_{\text {hitung }}>\mathrm{r}_{\text {tabel }}: \mathrm{a}<0,05$, maka dinyatakan valid.

b. Jika $r_{\text {hitung }}<r_{\text {tabel }}$ : a $>0,05$, maka dinyatakan tidak valid.

Tabel 1. Uji Validitas Keterlibatan Kerja

\begin{tabular}{|c|c|c|c|c|}
\hline \multicolumn{3}{|c|}{ Butir $r$ hitung $\mathrm{t}$ tabel } & gnifikansi & Keterangan \\
\hline 1 & 0,702 & 0,339 & 0,000 & Valid \\
\hline 2 & 0,646 & 0,339 & 0,000 & Valid \\
\hline 3 & 0,729 & 0,339 & 0,000 & Valid \\
\hline 4 & 0,731 & 0,339 & 0,000 & Valid \\
\hline
\end{tabular}

Tabel 3. Uji Validitas Komitmen Organisasi

\begin{tabular}{|c|c|c|c|c|}
\hline \multicolumn{3}{|c|}{ Butir $\mathrm{r}$ hitung $\mathrm{t}$ tabel } & Signifikansi & Keterangan \\
\hline 1 & 0,649 & 0,339 & 0,000 & Valid \\
\hline 2 & 0,755 & 0,339 & 0,000 & Valid \\
\hline 3 & 0,776 & 0,339 & 0,000 & Valid \\
\hline 4 & 0,783 & 0,339 & 0,000 & Valid \\
\hline 5 & 0,551 & 0,339 & 0,000 & Valid \\
\hline
\end{tabular}

Tabel 2. Uji Validitas Kepuasan Kerja

\begin{tabular}{ccccc}
\hline \multicolumn{3}{c}{ Butir } & $\mathrm{r}$ hitung $\mathrm{t}$ tabel & \multicolumn{3}{c}{ Signifikansi } & Keterangan \\
\hline 1 & 0,645 & 0,339 & 0,000 & Valid \\
2 & 0,678 & 0,339 & 0,000 & Valid \\
3 & 0,664 & 0,339 & 0,000 & Valid \\
4 & 0,766 & 0,339 & 0,000 & Valid \\
5 & 0,729 & 0,339 & 0,000 & Valid \\
\hline
\end{tabular}

Tabel 4. Uji Validitas Kinerja

\begin{tabular}{|c|c|c|c|c|}
\hline Butir & r hitun & t tabel & Signifikansi & Keterangan \\
\hline 1 & 0,763 & 0,339 & 0,000 & Valid \\
\hline 2 & 0,799 & 0,339 & 0,000 & Valid \\
\hline 3 & 0,834 & 0,339 & 0,000 & Valid \\
\hline 4 & 0,818 & 0,339 & 0,000 & Valid \\
\hline 5 & 0,628 & 0,339 & 0,000 & Valid \\
\hline
\end{tabular}

Berdasarkan tabel di atas, semua instrumen Keterlibatan Kerja, Kepuasan Kerja, Komitmen Organisasi dan Kinerja dinyatakan valid karena $r_{\text {hitung }}>r_{\text {tabel }}$ dan nilai signifikansi lebih kecil dari 0,05 sehingga semua item yang dipakai dinyatakan valid.

\section{Uji Reliabilitas}

Uji reliabilitas dilakukan dengan ketentuan bahwa suatu kuesioner dinyatakan reliabel apabila jawaban responden terhadap pernyataan yang digunakan konsisten dengan melihat hasil koefisien Cronbach Alpha > 0,60 atau 60\% menurut Ghozali (2009: 48).

Tabel 5. Uji Reliabilitas

\begin{tabular}{lccc}
\hline \multicolumn{1}{c}{ Item Variabel } & $\begin{array}{c}\text { Nilai Cronbach Alpha } \\
\text { Minimum }\end{array}$ & Cronbach Alpha & $\begin{array}{c}\text { Keteranga } \\
\mathrm{n}\end{array}$ \\
\hline Keterlibatan Kerja (X1) & 0,60 & 0,652 & Reliabel \\
Kepuasan Kerja (X2) & 0,60 & 0,726 & Reliabel \\
Komitmen Organisasi (Y1) & 0,60 & 0,745 & Reliabel \\
Kinerja (Y2) & 0,60 & 0,827 & Reliabel \\
\hline
\end{tabular}

Berdasarkan tabel 5, hasil analisis dapat dijelaskan bahwa seluruh variabel yang digunakan dalam penelitian ini dinyatakan reliabel karena Cronbach Alpha dari masing-masing variabel nilainya lebih dari $>0,60$. 


\section{Uji Asumsi Klasik}

\section{Uji Multikolinearitas}

Tabel 6. Hasil Uji Multikolinearitas Sub Struktural I

\begin{tabular}{lrc}
\hline \multirow{2}{*}{ Model } & \multicolumn{2}{c}{ Collinearity Statistics } \\
\cline { 2 - 3 } Keterlibatan Kerja & Tolerance & VIF \\
Kepuasan Kerja & 0,734 & 1,362 \\
\end{tabular}

Tabel 7. Hasil Uji Multikolinearitas Sub Struktural II

\begin{tabular}{lcc}
\hline \multirow{2}{*}{ Model } & \multicolumn{2}{c}{ Collinearity Statistics } \\
\cline { 2 - 3 } Keterlibatan Kerja & Tolerance & VIF \\
Kepuasan Kerja & 0,411 & 2,430 \\
Komitmen Organisasi & 0,535 & 1,871 \\
\hline
\end{tabular}

Berdasarkan tabel di atas dijelaskan bahwa pada bagian Collinearity Statistics menunjukkan angka VIF di bawah 10 dan Tolerance di atas 0,1, dengan demikian dapat dikatakann bahwa pada model regresi ini tidak terdapat gejala multikolinearitas sehingga model regresi pada penelitian ini dapat digunakan.

\section{Uji Heteroskedastisitas}

\section{Gambar 2. Hasil Uji Heterosdetastisitas}

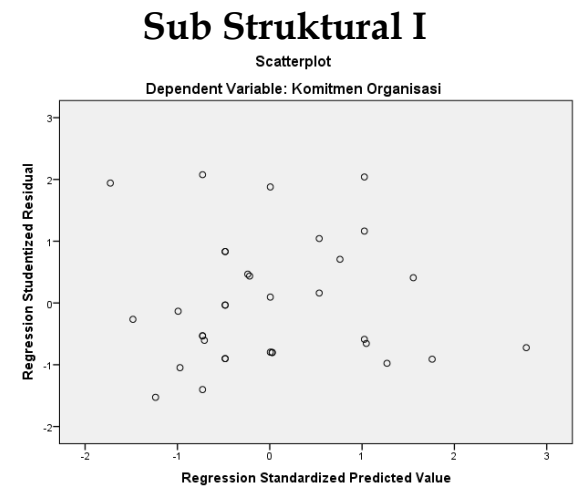

\section{Gambar 3. Hasil Uji Heteroskedastisitas} Sub Struktural II

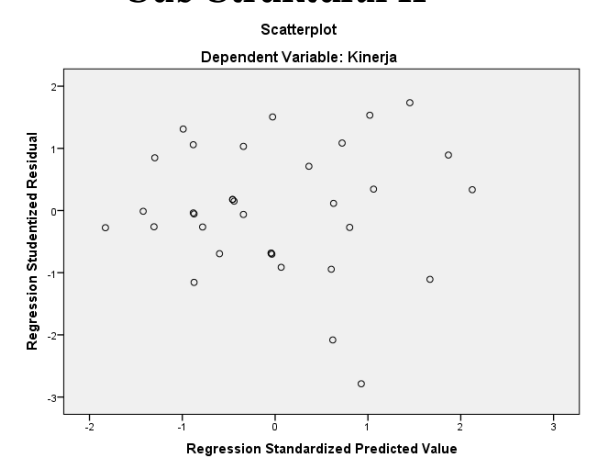

Berdasarkan gambar di atas, menunjukkan bahwa tidak ada pola tertentu, seperti titik-titik yang membentuk pola tertentu yang jelas serta menyebar di atas dan di bawah angka ) pada sumbu Y, maka dapat disimpulkan bahwa model regresi dalam penelitian ini tidak terjadi gejala heteroskedastisitas. 


\section{Uji Normalitas}

Tabel 8. Hasil Uji Kolmogorov-Smirnov Sub Struktural I

\begin{tabular}{llr}
\hline & & Unstandardized Residual \\
\hline $\mathrm{N}$ & Mean & 34 \\
Normal Parametersa,b & Std. Deviation &, 0000000 \\
& Absolute & 1,14168485 \\
& Positive &, 175 \\
Most Extreme Differences &, 175 \\
& Negative &,- 091 \\
Kolmogorov-Smirnov Z & & 1,019 \\
Asymp. Sig. (2-tailed) & &, 251 \\
\hline
\end{tabular}

Berdasarkan tabel di atas menunjukkan bahwa nilai signifikansi Ssymp.sig. (2-tailed sebesar $0,251>0,05)$. Sehingga dapat disimpulkan bahwa data berdistribusi normal.

Tabel 9. Hasil Uji Kolmogorov-Smirnov Sub Struktural II

\begin{tabular}{llr}
\hline & & Unstandardized Residual \\
\hline $\mathrm{N}$ & & 34 \\
Normal Parametersa,b & Mean &, 0000000 \\
& Std. Deviation &, 89531734 \\
& Absolute &, 101 \\
Most Extreme Differences & Positive &, 082 \\
& Negative & -101 \\
Kolmogorov-Smirnov Z & &, 587 \\
Asymp. Sig. (2-tailed) & &, 881 \\
\hline
\end{tabular}

Berdasarkan tabel di atas menunjukkan bahwa nilai signifikansi Ssymp.sig (2-tailed sebesar $0,881>0,05)$. Sehingga dapat disimpulkan bahwa data berdistribusi normal.

\section{Uji Hipotesis}

Uji $t$

Tabel 10. Uji t Sub Struktural I

\begin{tabular}{|c|c|c|c|c|c|}
\hline \multirow[t]{2}{*}{ Model } & \multicolumn{2}{|c|}{$\begin{array}{c}\text { Unstandardized } \\
\text { Coefficients }\end{array}$} & \multirow{2}{*}{$\begin{array}{c}\begin{array}{c}\text { Standardized } \\
\text { Coefficients }\end{array} \\
\text { Beta } \\
\end{array}$} & \multirow[t]{2}{*}{$\mathrm{t}$} & \multirow[t]{2}{*}{ Sig. } \\
\hline & B & Std. Error & & & \\
\hline (Constant) & $-2,035$ & 2,117 & &,- 961 & 344 \\
\hline 1 Keterlibatan Kerja & ,889 & 180 & ,566 & 4,931 & ,000 \\
\hline Kepuasan Kerja & ,427 & 125 & 390 & 3,402 & ,002 \\
\hline
\end{tabular}

a. Hubungan Keterlibatan Kerja dan Komitmen Organisasi

Hasil uji t pada tabel di atas menunjukkan bahwa probabilitas signifikansi untuk variabel keterlibatan kerja sebesar $0,000<0,05$ dan hasil perhitungan diperoleh angka $t_{\text {hitung }} 4,931>$ $t_{\text {tabel }} 2,039$. Hasil ini menyatakan bahwa hipotesis H1 diterima yang artinya keterlibatan kerja memiliki pengaruh positif dan signifikan terhadap komitmen organisasi Pegawai PNS di Dinas Sosial dan Pengendalian Penduduk dan Keluarga Berencana Kabupaten Kebumen. 
b. Hubungan Kepuasan Kerja dan Komitmen Organisasi

Hasil uji t pada tabel di atas menunjukkan bahwa probabilitas signifikansi untuk variabel kepuasan kerja sebesar 0,002 < 0,05 dan hasil perhitungan diperoleh angka thitung 3,402 > ttabel 2,039. Hasil ini menyatakan bahwa hipotesis $\mathrm{H} 2$ diterima yang berarti kepuasan kerja memiliki pengaruh positif dan signifikan terhadap komitmen organisasi pegawai PNS di Dinas Sosial dan Pengendalian Penduduk dan Keluarga Berencana Kabupaten Kebumen.

Tabel 11. Uji t Sub Struktural II

\begin{tabular}{|c|c|c|c|c|c|c|c|}
\hline \multirow{2}{*}{\multicolumn{2}{|c|}{ Model }} & \multicolumn{2}{|c|}{$\begin{array}{l}\text { Unstandardized } \\
\text { Coefficients }\end{array}$} & \multirow{2}{*}{$\begin{array}{c}\begin{array}{c}\text { Standardized } \\
\text { Coefficients }\end{array} \\
\text { Beta } \\
\end{array}$} & & \multirow[t]{2}{*}{$\mathrm{t}$} & \multirow[t]{2}{*}{ Sig. } \\
\hline & & $\mathrm{B}$ & Std. Error & & & & \\
\hline \multirow{4}{*}{1} & (Constant) & 148 & 1,713 & & & ,086 & ,932 \\
\hline & Keterlibatan Kerja & ,221 & 192 & & 140 & 1,151 & 259 \\
\hline & Kepuasan Kerja & ,015 & 117 & & ,014 & 131 & ,897 \\
\hline & Komitmen Organisasi & 787 & 143 & & 783 & 5,497 & ,000 \\
\hline
\end{tabular}

\section{a. Hubungan Keterlibatan Kerja dan Kinerja}

Hasil uji t pada tabel di atas menunjukkan bahwa probabilitas signifikansi untuk variabel Keterlibatan Kerja sebesar 0,259 > 0,05 dan hasil perhitungan diperoleh angka $t_{\text {hitung }} 1,151<$ $t_{\text {tabel }} 2,039$. Hasil ini menyatakan bahwa hipotesis H3 ditolak yang berarti Keterlibatan Kerja memiliki pengaruh negatif dan tidak signifikan terhadap Kinerja Pegawai PNS di Dinas Sosial dan Pengendalian Penduduk dan Keluarga Berencana Kabupaten Kebumen.

b. Hubungan Kepuasan Kerja dan Kinerja

Hasil uji t pada tabel di atas menunjukkan bahwa probabilitas signifikansi untuk variabel Kepuasan Kerja sebesar 0,897 > 0,05 dan hasil perhitungan diperoleh angka $t_{\text {hitung }} 0,131<$ $t_{\text {tabel }} 2,039$. Hasil ini menyatakan bahwa hipotesis H4 ditolak yang berarti Kepuasan Kerja memiliki pengaruh negatif dan tidak signifikan terhadap Kinerja Pegawai PNS di Dinas Sosial dan Pengendalian Penduduk dan Keluarga Berencana Kabupaten Kebumen.

c. Hubungan Komitmen Organisasi dan Kinerja

Hasil uji t pada tabel di atas menunjukkan bahwa probabilitas signifikansi untuk variabel Komitmen Organisasi sebesar 0,000 $<0,05$ dan hasil perhitungan diperoleh angka $t_{\text {hitung }}$ $5,497>t_{\text {tabel }} 2,039$. Hasil ini menyatakan bahwa hipotesis H5 diterima yang berarti Komitmen Organisasi memiliki pengaruh positif dan signifikan terhadap Kinerja Pegawai PNS di Dinas Sosial dan Pengendalian Penduduk dan Keluarga Berencana Kabupaten Kebumen.

\section{Koefisien Determinasi}

\section{Tabel 12. Uji Koefisien Determinasi Sub Struktural I}

\begin{tabular}{lrrrr}
\hline Model & $\mathrm{R}$ & R Square & Adjusted R Square & Std. Error of the Estimate \\
\hline 1 &, $837 \mathrm{a}$ &, 700 &, 681 & 1,178 \\
\hline
\end{tabular}

Berdasarkan hasil tabel di atas, hasil uji menunjukkan bahwa nilai adjusted $R$ Square persamaan I sebesar 0,681 artinya 68,1 \% variabel Komitmen Organisasi dapat dijelaskan oleh variabel Keterlibatan Kerja dan Kepuasan Kerja. Sedangkan sisanya 31,9 \% dapat dijelaskan oleh variabel lain diluar model penelitian ini. 
Tabel 13. Uji Koefisien Determinasi Sub Struktural II

\begin{tabular}{lrrrr}
\hline Model & $\mathrm{R}$ & R Square & Adjusted R Square & Std. Error of the Estimate \\
\hline 1 &, $904^{\mathrm{a}}$ &, 818 &, 799 &, 939 \\
\hline
\end{tabular}

Berdasarkan hasil tabel di atas, hasil uji menunjukkan bahwa nilai adjusted $R$ Square persamaan II sebesar 0,799, artinya 79,9 \% variabel Kinerja dapat dijelaskan oleh variabel Keterlibatan Kerja dan Kepuasan Kerja dan Komitmen Organisasi. Sedangkan sisanya 20,1 \% dapat dijelaskan oleh variabel lain diluar model penelitian ini.

\section{Analisis Korelasi}

Tabel 14. Hasil Uji Analisis Korelasi

\begin{tabular}{llrr}
\hline & & Keterlibatan Kerja & Kepuasan Kerja \\
\hline \multirow{2}{*}{ Keterlibatan Kerja } & Pearson Correlation & 1 &, $516^{* *}$ \\
& Sig. (1-tailed) & &, 001 \\
& N & 34 & 34 \\
& Pearson Correlation &, $516^{* *}$ & 1 \\
Kepuasan Kerja & Sig. (1-tailed) &, 001 & 34 \\
& N & 34 & 34 \\
\hline
\end{tabular}

Berdasarkan Tabel IV-19 di atas, maka angka korelasi variabel Keterlibatan Kerja dan variabel Kepuasan Kerja adalah sebesar 0,561 yang mempunyai maksud hubungan antara kedua variabel tersebut kuat dan searah (karena hasilnya positif). Korelasi dua variabel bersifat signifikan karena angka signifikan sebesar 0,001<0,05.

\section{Sobel Test}

Tabel 15. Hasil Uji Sobel Sub Struktural I

\begin{tabular}{ccc}
\hline Test Statistic & Standar Error & P-Value \\
\hline 3,67577856 & 0,19033872 & 0,00023713 \\
\hline
\end{tabular}

Berdasarkan tabel di atas, menunjukkan bahwa hasil test statistic $<t_{\text {tabel }}$ yaitu 3,67577856 $>$ 2,039151 dan $p$-value < a yaitu 0,000 < 0,05. Maka dapat dikatakan bahwa Komitmen Organisasi dapat memediasi Keterlibatan Kerja dan Kinerja.

Tabel 16. Hasil Uji Sobel Sub Struktural II

\begin{tabular}{ccc}
\hline Test Statistic & Standar Error & P-Value \\
\hline 2,90236215 & 0,111578466 & 0,0037036 \\
\hline
\end{tabular}

Berdasarkan tabel di atas, menunjukkan bahwa hasil test statistic $<t_{\text {tabel }}$ yaitu 2,90236215 $>$ 2,039151 dan $p$-value < a yaitu 0,003 < 0,05. Maka dapat dikatakan bahwa Komitmen Organisasi dapat memediasi Kepuasan Kerja dan Kinerja.

\section{Analisis Jalur}

Analisis jalur adalah analisis yang menghubungkan lebih dari dua variabel. Untuk mengetahui hubungan Keterlibatan Kerja (X1), Kepuasan Kerja (X2), Komitmen Organisasi (Y1) dan Kinerja (Y2) dapat digunakan rumus:

$$
\begin{aligned}
& Y 1=0,566 X_{1}+0,390 X_{2}+€_{1} \\
& \text { Dimana } €=\sqrt{ } 1-R^{2}=\sqrt{ } 1-0,700=\sqrt{ } 0,3=0,548
\end{aligned}
$$


Kemudian dapat dijelaskan sebagai berikut:

a. Koefisien regresi variabel X1 sebesar 0,566 menunjukkan bahwa dengan adanya variabel Keterlibatan Kerja akan meningkatkan Komitmen Organisasi pada Pegawai PNS di Dinas Sosial dan Pengendalian Penduduk dan Keluarga Berencana Kabupaten Kebumen sebesar 0,566. Hal ini menunjukkan bahwa semakin tinggi nilai koefisien Keterlibatan Kerja berarti Komitmen Organisasi pada Pegawai PNS di Dinas Sosial dan Pengendalian Penduduk dan Keluarga Berencana Kabupaten Kebumen semakin meningkat.

b. Koefisien regresi X2 sebesar 0,390 menunjukkan bahwa dengan adanya variabel Kepuasan Kerja akan meningkatkan Komitmen Organisasi pada Pegawai PNS di Dinas Sosial dan Pengendalian Penduduk dan Keluarga Berencana Kabupaten Kebumen sebesar 0,390. Hal ini menunjukkan bahwa semakin tinggi nilai koefisien Kepuasan Kerja berarti Komitmen Organisasi pada Pegawai PNS di Dinas Sosial dan Pengendalian Penduduk dan Keluarga Berencana Kabupaten Kebumen semakin meningkat.

c. Nilai residual atau eror sebesar 0,548 menunjukkan bahwa Komitmen Organisasi pada pada Pegawai PNS di Dinas Sosial dan Pengendalian Penduduk dan Keluarga Berencana Kabupaten Kebumen tidak dapat dijelaskan oleh variabel Keterlibatan Kerja dan Kepuasan Kerja sebesar 0,548 dengan persentase $54,8 \%$.

$$
\begin{aligned}
& Y_{2}=0,140 X_{1}+0,014 X_{2}+0,783 Y_{1}+€_{1} \\
& \text { Dimana } €=\sqrt{ } r-R^{2}=\sqrt{ } 1-0,818=\sqrt{ } 0,182=0,427
\end{aligned}
$$

Kemudian dapat dijelaskan sebagai berikut:

a. Koefisien regresi X1 sebesar 0,140 menunjukkan bahwa dengan adanya variabel Keterlibatan Kerja akan meningkatkan Kinerja pada Pegawai PNS di Dinas Sosial dan Pengendalian Penduduk dan Keluarga Berencana Kabupaten Kebumen sebesar 0,140. Hal ini menunjukkan bahwa semakin tinggi nilai koefisien Keterlibatan Kerja berarti Kinerja pada Pegawai PNS di Dinas Sosial dan Pengendalian Penduduk dan Keluarga Berencana Kabupaten Kebumen semakin meningkat.

b. Koefisien regresi X2 sebesar 0,014 menunjukkan bahwa dengan adanya variabel Kepuasan Kerja akan menurunkan Kinerja pada Pegawai PNS di Dinas Sosial dan Pengendalian Penduduk dan Keluarga Berencana Kabupaten Kebumen sebesar 0,014. Hal ini menunjukkan bahwa semakin rendah nilai koefisien Kepuasan Kerja berarti Kinerja pada Pegawai PNS di Dinas Sosial dan Pengendalian Penduduk dan Keluarga Berencana Kabupaten Kebumen semakin rendah.

c. Koefisien regresi Y1 sebesar 0,783 menunjukkan bahwa dengan adanya variabel Komitmen Organisasi akan meningkatkan Kinerja pada Pegawai PNS di Dinas Sosial dan Pengendalian Penduduk dan Keluarga Berencana Kabupaten Kebumen sebesar 0,783. Hal ini menunjukkan bahwa semakin tinggi nilai koefisien Komitmen Organisasi berarti Kinerja pada Pegawai PNS di Dinas Sosial dan Pengendalian Penduduk dan Keluarga Berencana Kabupaten Kebumen semakin meningkat.

d. Nilai residual atau eror sebesar 0,427 menunjukkan bahwa Kinerja pada pada Pegawai PNS di Dinas Sosial dan Pengendalian Penduduk dan Keluarga Berencana Kabupaten Kebumen tidak dapat dijelaskan oleh variabel Keterlibatan Kerja dan Kepuasan Kerja dan Komitmen Organisasi sebesar 0,427 dengan persentase $42,7 \%$. 


\section{Diagram Jalur}

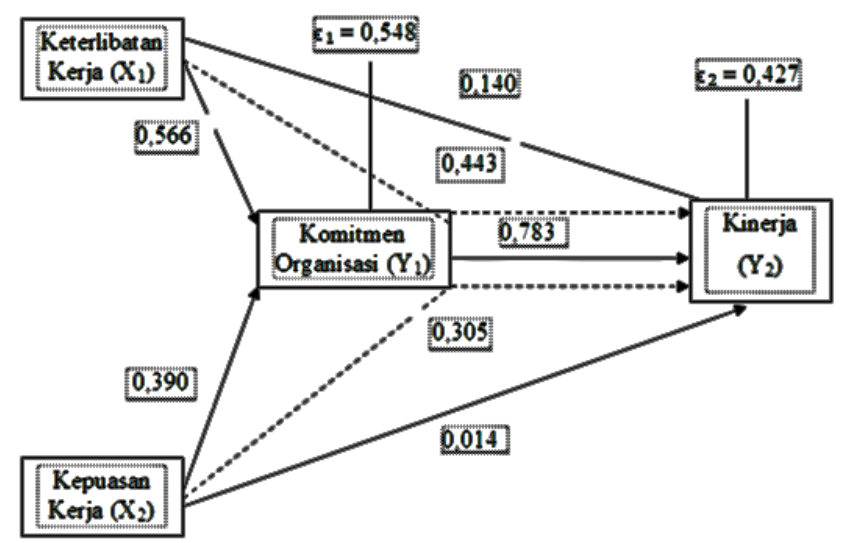

Gambar 4. Diagram Jalur

Berdasarkan gambar di atas mengenai Diagram Analisis Jalur dijelaskan bahwa variabel Keterlibatan Kerja berpengaruh sebesar 0,566 terhadap variabel Komitmen Organisasi, variabel Kepuasan Kerja sebesar 0,390 terhadap Komitmen Organisasi, Keterlibatan Kerja berpengaruh sebesar 0,140 terhadap variabel Kinerja, variabel Kepuasan Kerja sebesar 0,014 terhadap Kinerja dan variabel Komitmen Organisasi berpengaruh sebesar 0,783 terhadap Kinerja. Korelasi antar variabel Keterlibatan Kerja dan variabel Kepuasan Kerja adalah 0,516.

\section{Penutup dan Saran}

\section{Simpulan}

1. Keterlibatan Kerja berpengaruh positif dan signifikan terhadap Komitmen Organisasi pada Pegawai PNS di Dinas Sosial dan Pengendalian Penduduk dan Keluarga Berencana Kabupaten Kebumen.

2. Kepuasan Kerja berpengaruh positif dan signifikan terhadap Komitmen Organisasi pada Pegawai PNS di Dinas Sosial dan Pengendalian Penduduk dan Keluarga Berencana Kabupaten Kebumen.

3. Keterlibatan Kerja tidak berpengaruh terhadap Kinerja pada Pegawai PNS di Dinas Sosial dan Pengendalian Penduduk dan Keluarga Berencana Kabupaten Kebumen.

4. Kepuasnan Kerja tidak berpengaruh terhadap Kinerja pada Pegawai PNS di Dinas Sosial dan Pengendalian Penduduk dan Keluarga Berencana Kabupaten Kebumen.

5. Komitmen Organisasi berpengaruh positif dan signifikan terhadap Kinerja pada Pegawai PNS di Dinas Sosial dan Pengendalian Penduduk dan Keluarga Berencana Kabupaten Kebumen.

6. Keterlibatan Kerja berpengaruh tidak langsung terhadap Kinerja melalui Komitmen Organisasi pada Pegawai PNS di Dinas Sosial dan Pengendalian Penduduk dan Keluarga Berencana Kabupaten Kebumen.

7. Kepuasan Kerja berpengaruh tidak langsung terhadap Kinerja melalui Komitmen Organisasi pada Pegawai PNS di Dinas Sosial dan Pengendalian Penduduk dan Keluarga Berencana Kabupaten Kebumen.

\section{Keterbatasan}

1. Penelitian ini merupakan penelitian kuantitatif dengan teknik pengumpulan data menggunakan kuesioner, wawancara dan studi pustaka.

2. Temuan penelitian ini dapat digunakan di Dinas Sosial dan pengendalian Penduduk dan Keluarga Berencana Kabupaten Kebumen saja. Penelitian selanjutnya dapat memperluas populasi penelitian. 
3. Penelitian ini belum dapat mengungkapkan secara keseluruhan faktor yang mempengaruhi Kinerja dalam penelitian ini hanya Keterlibatan Kerja, Kepuasan Kerja dan Komitmen Organisasi. Penelitian selanjutnya diharapkan dapat menggunakan variabel lain yang dapat mempengaruhi kinerja.

\section{Implikasi}

\section{Implikasi Praktis}

1. Keterlibatan kerja berpengaruh terhadap komitmen organisasi. Artinya semakin tinggi keterlibatan kerja akan mampu meningkatkan komitmen organisasi. Dinas Sosial dan Pengendalian Penduduk dan Keluarga Berencana Kabupaten Kebumen dalam melaksanakan tugas di organisasinya untuk lebih ditingkatkan dalam bekerjanya dengan profesional untuk kelancaran tugas yang diberikannya.

2. Kepuasan kerja berpengaruh terhadap komitmen organisasi. Artinya semakin tinggi nilai kepuasan kerja yang dimiliki pegawai akan meningkatkan komitmen organisasi. Dinas Sosial dan Pengendalian Penduduk dan Keluarga Berencana Kabupaten Kebumen perlu memberikan sikap dan perasaan yang diterima pegawai melalui hal-hal yang dapat mendorong atau hal yang dapat membuat pegawai termotivasi. Sehingga akan membuat pegawai tetap bertahan dan berkomitmen di dalam organisasi.

3. Komitmen organisasi berpengaruh terhadap kinerja. Artinya semakin tinggi komitmen organisasi yang dimiliki pegawai akan meningkatkan kinerja. Dinas Sosial dan Pengendalian Penduduk dan Keluarga Berencana Kabupaten Kebumen dalam meningkatkan komitmen organisasi perlu memberikan kesempatan kepada pegawai untuk mengembangkan kemampuan yang dimiliki dan meningkatkan keinginan untuk melakukan sutau karya yang berprestasi. Sehingga pegawai tersebut tetap bekerja di organisasi dengan baik dan akan berkomitmen untuk tetap bekerja di dalam organisasi.

\section{Implikasi Teoritis}

1. Berdasarkan hasil analisis data yang dilakukan oleh penulis bahwa keterlibatan kerja tidak berpengaruh terhadap kinerja pegawai PNS di Dinas Sosial dan Pengendalian Penduduk dan Keluarga Berencana Kabupaten Kebumen. Hal ini berarti keterlibatan kerja tidak memiliki hubungan yang besar terhadap meningkatnya kinerja pegawai PNS di Dinas Sosial dan Pengendalian Penduduk dan Keluarga Berencana Kabupaten Kebumen. Hal ini sejalan dengan hasil penelitian yang dilakukan oleh Hidayat, dkk (2019) yang menyatakan bahwa keterlibatan kerja tidak berpengaruh secara signifikan terhadap kinerja.

2. Berdasarkan hasil analisis data yang dilakukan oleh penulis bahwa kepuasan kerja tidak berpengaruh terhadap kinerja pegawai PNS di Dinas Sosial dan Pengendalian Penduduk dan Keluarga Berencana Kabupaten Kebumen. Hal ini berarti semakin tinggi atau rendahnya kepuasan kerja yang terjadi, tidak akan berpengaruh terhadap meningkatnya kinerja pegawai PNS di Dinas Sosial dan Pengendalian Penduduk dan Keluarga Berencana Kabupaten Kebumen. Hal ini sejalan dengan hasil penelitian yang dilakukan oleh Arianto, Deny (2017) yang menyatakan bahwa kepuasan kerja tidak meiliki pengaruh yang tidak signifikan terhadap kinerja karyawan.

3. Berdasarkan hasil analisis data yang dilakukan oleh penulis bahwa komitmen organisasi berpengaruh terhadap kinerja pegawai PNS di Dinas Sosial dan Pengendalian Penduduk dan Keluarga Berencana Kabupaten Kebumen. Hal ini berarti komitmen organisasi apabila komitmen organisasi tinggi pegawai akan lebih meningkatkan kinerjanya. Hal ini sejalan dengan hasil penelitian yang dilakukan oleh Rosyidah, dkk (2018) yang menyatakan bahwa komitmen organisasi berpengaruh positif signifikan terhadap kinerja pegawai. 


\section{Referensi}

Arianto, D. (2017). Pengaruh kepuasan kerja terhadap kinerja karyawan melalui organizational citizenship behavior sebagai variabel intervening (studi pada staff pt kepuh kencana arum mojokerto. Jurnal Ilmu Manajemen (JIM), 5(3), 1-9.

Ghozali, I. (2009). Aplikasi Analisis Multivariet dengan Program SPSS. Edisi Keempat. Semarang: Universitas Diponegoro.

Handayani, D. L. (2011). Komitmen Organisasi Merupakan Variabel Intervening Pengaruh Antara Kepuasan Kerja Terhadap Kinerja Pegawai. Jurnal Ilmu Manajemen dan Akuntansi Terapan (JIMAT), 2(2).

Hasibuan, M. (2002). Manajemen Sumber Daya Manusia. Jakarta: Bumi Aksara.

Hasibuan, M. (2007). Manajemen Dasar, Pengertian dan Masalah. Cetakan Kesepuluh. Jakarta: PT. Bumi Aksara.

Indra, D., Iskandar, Y., \& Faruk, M. (2019). Pengaruh Keterlibatan Kerja Dan Kohesivitas Dalam Kelompok Kerja Terhadap Kinerja Karyawan (Suatu Studi pada Lembaga Pemasyarakatan Kelas II-B Ciamis). Business Management and Entrepreneurship Journal, 1(4), 193-205.

Luthas, F. (2006). Perilaku Organisasi. Edisi Sepuluh. Yogyakarta: PT. Andi.

Mangkunegara. (2000). Manajemen Sumber Daya Manusia Perusahaan. Bandung: Remaja Rosdakarya.

Rivai, V., \& Mulyad, D. (2012). Kepemimpinan dan Perilaku Organisasi. Edisi ketiga. Jakarta: PT. Raja Grafindo Persada.

Robbins, S. P. (2006). Perilaku Organisasi. Edisi sepuluh. Jakarta: PT. Indeks.

Robbins, S. P. (2013). Perilaku Organisasi. Jakarta: PT. Indeks.

Robbins, S. P., \& Judge, T. (2008). Perilaku Organisasi. Jakarta: Salemba Empat.

Robbins, S. P., \& Judge, T. (2010). Essentials of Organizational Behavior. 10 $0^{\text {th }}$ Edition. New Jersey: Pearson Education.

Rosyidah, E., Fadah, I., \& Tobing, D. S. K. (2018). Pengaruh Kepuasan Kerja Dan Budaya Organisasi Terhadap Kinerja Pegawai Melalui Komitmen Organisasi Di Unit-Unit Pelayanan Publik Kabupaten Jember. Relasi: Jurnal Ekonomi, 14(1), 1-16.

Soegihartono, 2012, Pengaruh Kepemimpinan dan Kepuasan Kerja Terhadap Kinerja dengan Mediasi Komitmen (di PT Alam Kayu Sakti Semarang), Jurnal Mitra Ekonomi dan Manajemen Bisnis, Vol.3, No. 1, April 2012, 123-140. 